\title{
Effect of Different Cations in Pickling Solution on FTIR Characteristics of Pidan White and Yolk in Comparison to the Fresh Duck Egg
}

(Kesan Kation Berbeza dalam Larutan Jeruk ke atas Ciri FTIR Putih dan Kuning Pidan Berbanding Telur Itik Segar)

\author{
PALANIVEL GANESAN*, SOOTTAWAT BENJAKUL\& BADLISHAH SHAM BAHARIN
}

\begin{abstract}
Fourier transform infrared (FTIR) study of pidan white and yolk treated with different cations were investigated in comparison to the fresh duck egg. FTIR study of $\mathrm{PbO}_{2}$ and $\mathrm{ZnCl}$, treated pidan white and yolk at a level of $2 \mathrm{~g} \mathrm{~kg}^{-1} \mathrm{had}$ different spectra to those of fresh egg. The amide B with wavenumbers of 3083 and $3084 \mathrm{~cm}^{-1}$ was observed for fresh and $\mathrm{PbO}$, treated pidan white at a level of $2 \mathrm{~g} \mathrm{~kg}^{-1}$. Higher wavenumber of $3084 \mathrm{~cm}^{-1}$ was noticeable for PbO, treated pidan white at a level of $2 \mathrm{~g} \mathrm{~kg}^{-1}$. Scanning electron microscopic study showed that the more ordered network was found in $\mathrm{PbO}_{2}$ treated pidan white at a level of $2 \mathrm{~g} \mathrm{~kg}^{-1}$, compared with $\mathrm{ZnCl}_{2}$ treated counterpart. Thus cations in the pickling solution affected the FTIR characterestics of pidan white and yolk.
\end{abstract}

Keywords: CLSM; FTIR; pidan; SEM

\section{ABSTRAK}

Penyelidikan transformasi Fourier inframerah (FTIR) putih dan kuning pidan yang dirawat dengan kation berbeza berbanding telur itik segar dikaji. Kajian FTIR $\mathrm{PbO}_{2}$ dan $\mathrm{ZnCl}_{2}$ putih dan kuning pidan pada tahap $2 \mathrm{~g} \mathrm{~kg}^{-1}$ mempunyai bilangan spektrum yang berbeza dengan telur segar. Amida B dengan gelombang nombor 3083 dan $3084 \mathrm{~cm}^{-1}$ diperhatikan pada $\mathrm{PbO}_{2}$ putih pidan yang dirawat pada tahap $2 \mathrm{~g} \mathrm{~kg}^{-1}$. Gelombang nombor yang lebih tinggi daripada $3084^{-1}$ adalah ketara bagi putih pidan dirawat dengan $\mathrm{PbO}_{2}$ pada tahap $2 \mathrm{~g} \mathrm{~kg}^{-1}$. Kajian microskopi imbasan elektron menunjukkan bahawa rangkaian lebih tersusun dilihat pada putih pidan $\mathrm{PbO}_{2}$ yang dirawat pada tahap $2 \mathrm{~g} \mathrm{~kg}^{-1}$, berbanding dengan yang dirawat oleh $\mathrm{ZnCl}_{2}$. Oleh itu kation dalam larutan jeruk memberi kesan kepada ciri FTIR putih dan kuning pidan.

Kata kunci: CLSM; FTIR; pidan; SEM

\section{INTRODUCTION}

Fourier transform infrared (FTIR) spectroscopic study is one of the powerful technique to study the intramolocular interaction of the food proteins in various foods (Boye et al. 1995). The intra molecular interaction of the proteins by thermally induced gelation of whey protein was studied using FTIR. Few researchers also reported the intermolecular interactions of fish proteins that involves in gelation and film formation using FTIR (Nagarajan et al. 2013; 2012). However, there was no report up to date regarding the FTIR study on the alkaine induced aggregation of duck egg protein. Pidan or alkaline treated egg have been known as preserved egg, consumed widely in southeast Asia. Pidan white is generally amber brown in color with the gelly texture, whereas pidan yolk is solidified with greenish brown color. Under alkaline $\mathrm{pH}$ used for pidan production, electrostatic repulsion extensively opposes protein-protein interactions. The addition of cations in pickling solution enhances the penetration of those cations into egg, thereby diminishing the repulsive forces and protein-protein association occurs, forming a self-supporting gel (Ganasen \& Benjakul 2011a, 2011b; 2010). Lead has been used in pidan for gel stabilisation but it is toxic for consumption (Chen \& Su 2004). Alternatively pidan is produced by soaking duck eggs in $\mathrm{NaOH}$ $\left(42 \mathrm{~g} \mathrm{~kg}^{-1}\right), \mathrm{NaCl}\left(50 \mathrm{~g} \mathrm{~kg}^{-1}\right)$ and divalent $\mathrm{ZnCl}_{2}\left(2 \mathrm{~g} \mathrm{~kg}^{-1}\right)$ or $\mathrm{CaCl}_{2}\left(2 \mathrm{~g} \mathrm{~kg}^{-1}\right)$ solution at room temperature $\left(30^{\circ} \mathrm{C}\right)$ for 3 weeks and ageing for another 3 weeks (Ganasen \& Benjakul 2011a, 2011b; 2010).

Alkaline treatment also causes the exceptional formations of lysinoalanine, racemisation of amino acids, aminoacids degradation and Maillard reactions during the processing of pidan (Chang et al. 1999). The formation of certain compounds in the Maillard reaction of pidan white is very complicated and the classes of compounds are more or less known. However, the characteristic texture and brown color of pidan white makes the product more consumable. Although the impact of cation types on the properties of pidan white and yolk has been elucidated (Ganasen \& Benjakul 2011a, 2011b; 2010). There was no information regarding the FTIR spectra analysis and microstructure of pidan white and yolk induced by selected cations has been reported. Therefore, the objective of this study was to characterize FTIR of pidan white and yolk during pickling in comparison to the fresh duck egg. 


\section{MATERIALS AND METHODS}

\section{CHEMICALS}

Lead oxide $\left(\mathrm{PbO}_{2}\right)$, zinc chloride $\left(\mathrm{ZnCl}_{2}\right)$, sodium hydroxide and sodium chloride were purchased from Lab-Scan (Bangkok, Thailand). Glutaraldehyde, ethanol and silver nitrate were obtained from Merck (Darmstadt, Germany). Nile blue A was procured from Merck (Darmstadt, Germany). Purity of all chemicals used was greater than $99 \%$.

\section{DUCK EGG COLLECTION}

Fresh duck eggs (Anas platyrhucus) with the weight range of 65-75 g were obtained within 1 day of laying from a farm in Rathabhum, Songhkla province, Thailand. Duck eggs were cleaned and checked for any crack prior to pickling.

\section{PREPARATION OF PIDAN}

Clean duck eggs were soaked in a pickling solution containing $\mathrm{NaOH}\left(42 \mathrm{~g} \mathrm{~kg}^{-1}\right), \mathrm{NaCl}\left(50 \mathrm{~g} \mathrm{~kg}^{-1}\right)$ and divalent $\mathrm{ZnCl}_{2}\left(2 \mathrm{~g} \mathrm{~kg}^{-1}\right)$. Traditionally prepared pidan using $\mathrm{PbO}_{2}$ at a level of $2 \mathrm{~g} \mathrm{~kg}^{-1}$ was used as the control. Sixty eggs were soaked in different pickling solutions $(6 \mathrm{~L})$ at room temperature $\left(30-32^{\circ} \mathrm{C}\right)$ for 3 weeks. Pidan were removed and coated with white clay paste (clay: water, $4: 1(\mathrm{w} / \mathrm{v})$ ) to obtain a thickness of 2-3 mm. Coated eggs were left at room temperature for another three weeks for ageing. The samples were then taken for analyses.

\section{FOURIER TRANSFORM INFRARED (FTIR) SPECTROSCOPY}

Prior to FTIR analysis the pellets containing $2 \mathrm{mg}$ freeze dried samples and approximately $100 \mathrm{mg}$ potassium bromide $(\mathrm{KBr})$ were prepared. All spectra were recorded using Bruker Model Vector 33 FTIR spectrometer (Bruker Co., Ettlingen, Germany) from 4000 to $400 \mathrm{~cm}^{-1}$ at a data acquisition rate of $4 \mathrm{~cm}^{-1}$ per point. Analysis of spectral data was carried out using the OPUS 3.0 data collection software programme (Bruker Co., Ettlingen, Germany).

\section{SCANNING ELECTRON MICROSCOPY (SEM) OF PIDAN WHITE}

Pidan white samples were broken into liquid nitrogen with an approximate size of $0.5 \times 0.5 \mathrm{~cm}^{2}$ and fixed at room temperature in $2.5 \%$ glutaraldehyde in $0.2 \mathrm{M}$ phosphate buffer (pH7.2) for $2 \mathrm{~h}$. Fixed samples were rinsed with distilled water three times to remove the salt. The samples were dehydrated in graded series of ethanol $(50,70,80$, 90 and $100 \mathrm{~g} \mathrm{~kg}^{-1}$ ) and then were mounted on SEM stubs using a double backed cellophane tape. The samples were coated with gold and examined using a scanning electron microscope (JEOL JSM-5800LV, Tokyo, Japan).

\section{CONFOCAL LASER SCANNING MICROSCOPY (CLSM) OF PIDAN YOLK}

Microstructures of pidan yolk treated samples were examined with a confocal laser scanning microscopy (Olympus, Fv300, Tokyo, Japan) following the modified method of Mineki and Kobayashi (1997). Yolk of fresh and all pidans was suspended in $0.1 \mathrm{~g} \mathrm{~kg}^{-1}$ Nile blue A solution at a ratio of $1: 10(\mathrm{w} / \mathrm{v})$ and manually stirred until the uniformity was obtained. Fifty $\mu \mathrm{L}$ of suspension was smeared on the microscopy slide. CLSM was operated in the fluorescence mode at the excitation wavelength of $533 \mathrm{~nm}$ and the emission wavelength of $630 \mathrm{~nm}$ using a Helium Neon Red laser (HeNe-R) for lipid analysis and at the excitation wavelength of $488 \mathrm{~nm}$ and the emission wavelength of $540 \mathrm{~nm}$ using a Helium Neon Green laser (HeNe-G) for protein analysis.

\section{STATISTICAL ANALYSIS}

All experiments were run in triplicate. The experimental data were subjected to analysis of variance (ANOVA) and the differences between means were evaluated by Duncan's new multiple range test (Steel \& Torrie 1980). Data analysis was performed using a SPSS package (SPSS 14.0 for Windows, SPSS Inc, Chicago, IL, USA).

\section{RESULTS AND DISCUSSION}

\section{FTIR SPECTRA OF WHITE AND YOLK} OF FRESH EGG AND PIDAN

FTIR spectra of egg white from fresh egg and pidan white are depicted in Figure 1(a). The absorption bands in the spectra of all white samples were situated in the amide band region such as amide I (1600-1700 $\mathrm{cm}^{-1)}$, amide II (1500-1600 $\left.\mathrm{cm}^{-1}\right)$, amide III $\left(1200-1300 \mathrm{~cm}^{-1}\right)$, amide A (3293-3306 $\left.\mathrm{cm}^{-1}\right)$, amide B $\left(2920-2922 \mathrm{~cm}^{-1}\right)$ and S-S $\left(400-500 \mathrm{~cm}^{-1}\right)$. For the spectrum of fresh egg white, the characteristic absorption bands at wavenumbers of 3303 , 3083, 1651, 1542, 1250 and $457 \mathrm{~cm}^{-1}$ were observed, whereas pidan treated with $\mathrm{PbO}_{2}$ and $\mathrm{ZnCl}_{2}$ at a level of $2 \mathrm{~g} \mathrm{~kg}^{-1}$ showed the main absorption bands at wavenumbers of 3305, 3084, 1651, 1542, 1239 and $465 \mathrm{~cm}^{-1}$ and 1652 1548 and $1242 \mathrm{~cm}^{-1}$. The amide I bands are originated from $\mathrm{CO}$ stretching vibrations coupled to $\mathrm{N}-\mathrm{H}$ bending vibrations, CN stretch and CCN deformation. For amide I band, fresh egg white had the lowest wave number, indicating the interaction of $\mathrm{CO}$ with the adjacent chains; while $\mathrm{ZnCl}_{2}$ treated pidan white at a level of $2 \mathrm{~g} \mathrm{~kg}^{-1}$ had the highest wave numbers. The amide II bands of all samples were obtained at different wavenumbers, representing $\mathrm{N}-\mathrm{H}$ bending vibrations coupled to $\mathrm{C}-\mathrm{N}$ stretching vibrations. Generally, the lower wavenumber showed the existence of hydrogen bonds, which were found in fresh egg white and $\mathrm{PbO}_{2}$ treated pidan white at a level of $2 \mathrm{~g} \mathrm{~kg}^{-1}$. The other bands, arising from the stretching vibrations of $\mathrm{N}-\mathrm{H}$ group, 
appeared at 3303 and $3305 \mathrm{~cm}^{-1}$, corresponding to amide A, which occurs commonly in the range of 3280-3300 $\mathrm{cm}^{-1}$. The amide B with wavenumbers of 3083 and 3084 $\mathrm{cm}^{-1}$ was observed for fresh and $\mathrm{PbO}_{2}$ treated pidan white at a level of $2 \mathrm{~g} \mathrm{~kg}^{-1}$. Higher wavenumber of $3084 \mathrm{~cm}^{-1}$ was noticeable for $0.2 \% \mathrm{PbO}_{2}$ treated pidan white. Amide $\mathrm{B}$ corresponds to asymmetric stretch vibration of $\mathrm{C}-\mathrm{H}$ as well as $-\mathrm{NH}_{3}$. The S-S with wavenumber $400-500 \mathrm{~cm}^{-1}$ was observed for fresh and $0.2 \% \mathrm{PbO}_{2}$ treated pidan white. Thus alkali penetration and cation binding of proteins in egg resulted in the changes in the structure of protein.

FTIR spectra of fresh egg yolk, $\mathrm{PbO}_{2}$ and $\mathrm{ZnCl}_{2}$ treated pidan yolk at a level of $2 \mathrm{~g} \mathrm{~kg}^{-1}$ are illustrated in Figure 1(b). The FTIR spectra shows different samples consisted of several peaks with different wavenumbers. Decrease in the absorbance band at $3600-3200 \mathrm{~cm}^{-1}$ was observed in $\mathrm{ZnCl}_{2}$ treated pidan yolk at a level of $2 \mathrm{~g} \mathrm{~kg}^{-1}$, indicating the loss of hydroperoxide, compared with that of fresh yolk. The result suggested that the decomposition of hydroperoxide took place, yielding the secondary lipid oxidation products during pidan production. Van de Voort et al. (1994) reported that the absorbance at $3800-3100 \mathrm{~cm}^{-1}$ in the ATR/FTIR spectra, referred to as the $\mathrm{OH}$ stretching region. Hydroperoxide moieties exhibit characteristic absorption bands between 3600 and $3400 \mathrm{~cm}^{-1}$ due to their $-\mathrm{OO}-\mathrm{H}$ stretching vibrations. Pidan treated with $\mathrm{PbO}_{2}$ at a level of $2 \mathrm{~g} \mathrm{~kg}^{-1}$ had no marked changes in this region, suggesting that lipid oxidation occurred at a low extent. Two stretched bands at wavenumbers of 2854 and $2924 \mathrm{~cm}^{-1}$ were due to the methylene asymmetrical and symmetrical stretching vibration, respectively (Guillen \& Cabo 1997). Both the methylene asymmetrical stretching bands at approximately $2925 \mathrm{~cm}^{-1}$ and the methylene symmetrical stretching band near $2854 \mathrm{~cm}^{-1}$ were obviously present in most of the lipid samples (Guillen et al. 2004). The bands associated with the fingerprint region observed between 1500 and $1000 \mathrm{~cm}^{-1}$ were not different between the fresh and pidan yolk. Carbonyl absorption of the triglyceride ester linkage was observed at $1746 \mathrm{~cm}^{-1}$ (Setiowaty et al. 2000). Yolk lipid mainly contained triglycerides with very low amounts of free fatty acids.

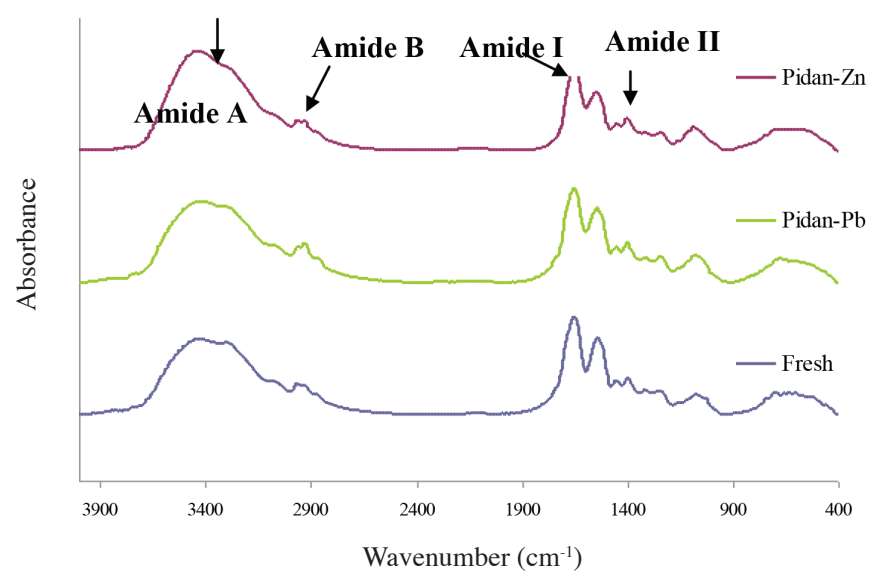

(a)

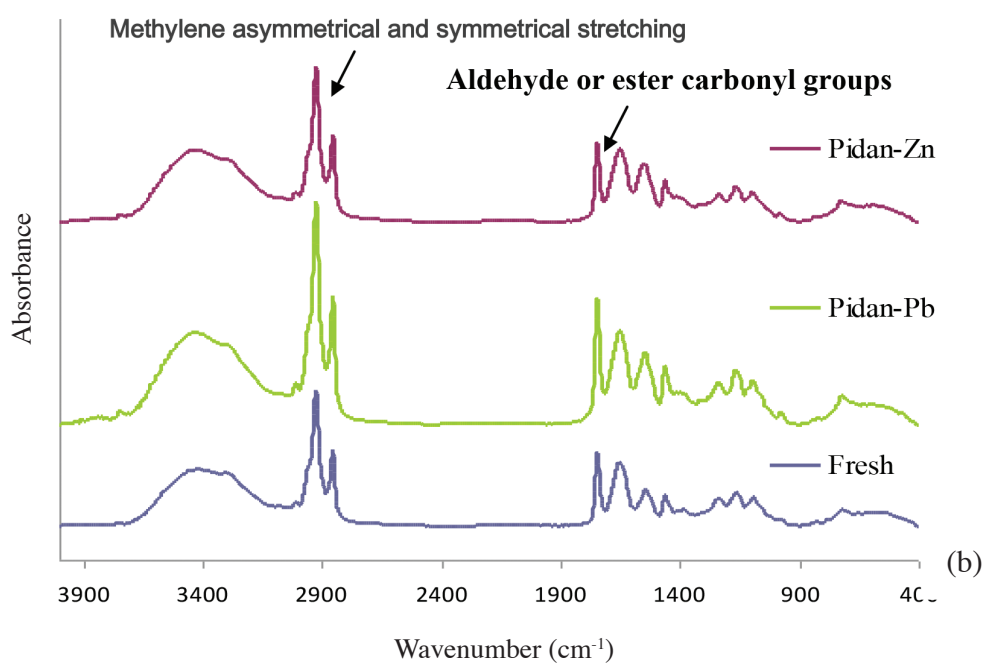

FIGURE 1. Fourier-transform infrared spectra of white and yolk of fresh egg and pidan Fresh:

Fresh egg yolk, Pidan- $\mathrm{Pb}: \mathrm{PbO}_{2}$ treated pidan, Pidan- $\mathrm{Zn}: \mathrm{ZnCl}_{2}$ treated pidan, pidan white (a) and pidan yolk (b) 


\section{MICROSTRUCTURE OF WHITE AND YOLK OF PIDAN}

Microstructures of pidan white treated with $\mathrm{PbO}_{2}$ and $\mathrm{ZnCl}_{2}$ at a level of $2 \mathrm{~g} \mathrm{~kg}^{-1}$ visualised by SEM are shown in Figure 2(a). Heterogeneous aggregates with the cracks were observed in pidan treated with $\mathrm{ZnCl}_{2}$. Pidan gels had more compact structure without the gap or void in the network when treated with $0.2 \% \mathrm{PbO}_{2}$ Rough surface of pidan was observed in pidan treated with $0.2 \% \mathrm{ZnCl}_{2}$ (Pidan-Zn) whereas highly cross-linked network with fine strands was found in pidan white treated with $\mathrm{PbO}_{2}$ (Pidan$\mathrm{Pb}$ ) at a level of $2 \mathrm{~g} \mathrm{~kg}^{-1}$ Woodward and Cotterill (1987) reported that egg white gel examined with SEM was very coarse with large irregularly shaped voids. Nevertheless, ovalbumin gels showed the homogeneous microstructure (Heertje \& Van Kleef 1986). The ordered structure of $\mathrm{PbO}_{2}$ treated pidan white at a level of $2 \mathrm{~g} \mathrm{~kg}^{-1}$ indicated that $\mathrm{Pb}$ cation somehow involved in the formation of gel network with high stability (Figure 2(a)). Alkaline conditions are known to unfold protein molecules (Creighton 1993). Those unfolded proteins could be cross-linked to form protein networks, particularly in the presence of cation via salt bridge mechanism. Thus, the appropriate cations most likely played an essential role in ion-induced gelation of pidan white.

The confocal laser scanning microscope (CLSM) micrographs of pidan yolk using a two channel technique, in which both protein and lipid were stained, are illustrated in Figure 2(b). Proteins in yolk were organized into micellar and granular structures together with polar and non-polar lipid molecules (Kiosseoglou 2003). When the penetration of alkali proceeded to interior yolk, 3 layers of pidan yolks were formed. Irregular shapes of both lipid and protein were found in both pidan yolk, irrespective of treatments. Nevertheless, the amount of lipid released and alteration of lipid shape were varied with the types of cation used. The greater release of free lipid from lipoprotein of
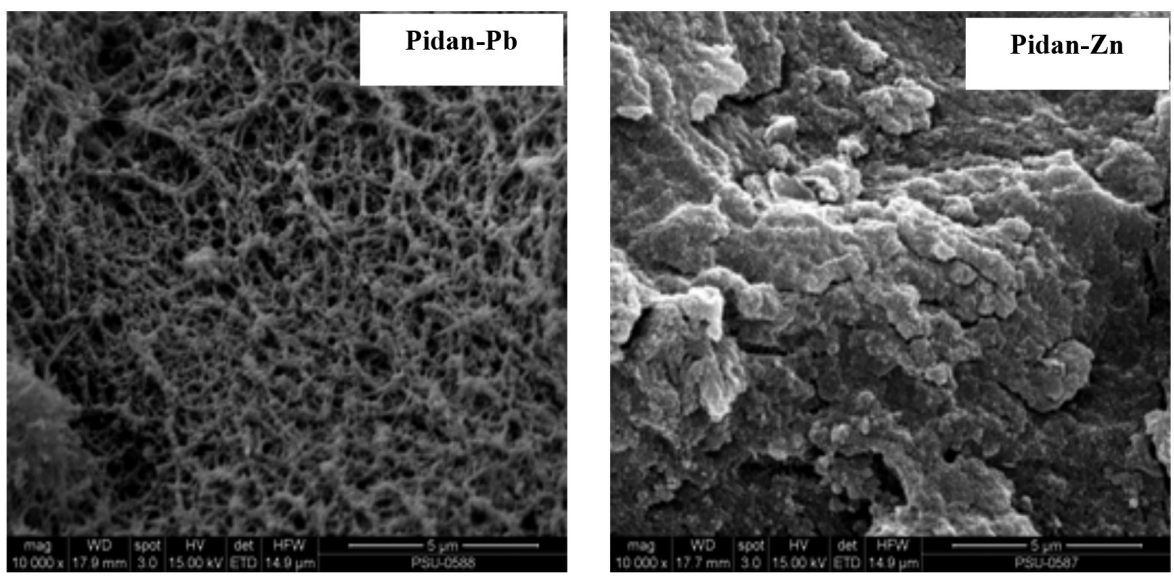

FIGURE 2(a). Scanning electron microscopic photograph of pidan white Magnification: $10000 \times$ Pidan $-\mathrm{Pb}: \mathrm{PbO}_{2}$ treated pidan white, Pidan- $\mathrm{Zn}: \mathrm{ZnCl}_{2}$ treated pidan white

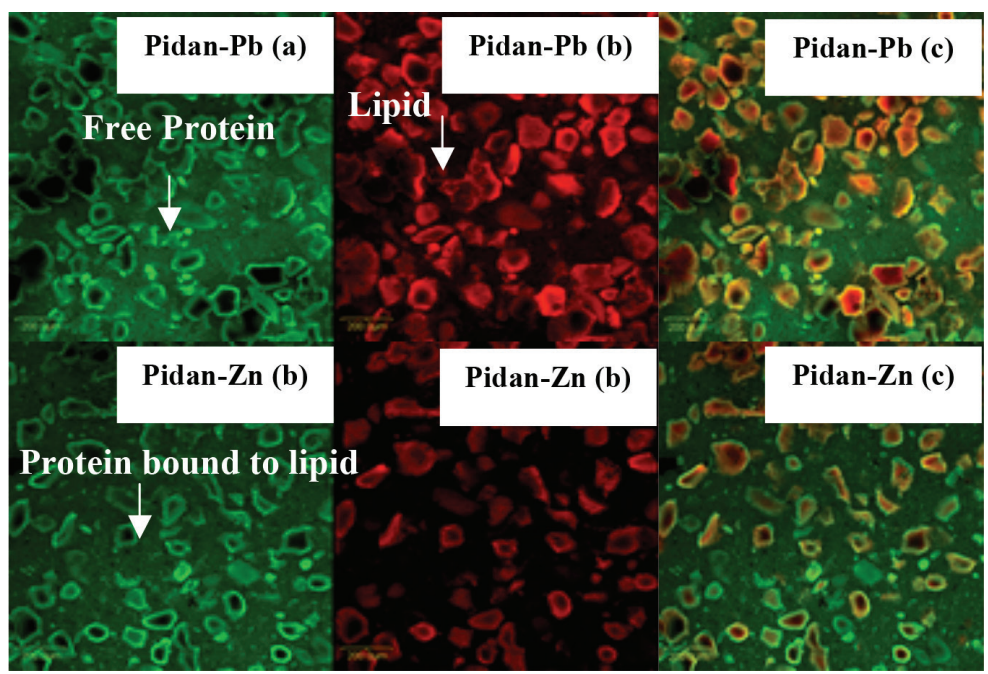

FIGURE 2(b). Confocal laser scanning microscope (CLSM) micrographs of pidan yolk Pidan-Pb: $\mathrm{PbO}_{2}$ treated pidan yolk, Pidan- $\mathrm{Zn}: \mathrm{ZnCl}_{2}$ treated pidan yolk Magnification: $200 \times($ zoom $\times 2.5)$ protein distribution (a) and lipid distribution (b) and combined image of protein and lipid (c) 
pidan yolk was obtained when $\mathrm{PbO}_{2}$ at a level of $2 \mathrm{~g} \mathrm{~kg}^{-1}$ was used as indicated by the denser lipid granules appeared in the combined image (Pidan- $\mathrm{Pb}(\mathrm{C})$ ). In the presence of alkali, saponified lipid was postulated to bind protein, leading to the formation of shielding surface. As a result, the dehydration was lowered and soft yolk pidan was obtained. CLSM micrograph of pidan treated with $\mathrm{ZnCl}_{2}$ at a level of $2 \mathrm{~g} \mathrm{~kg}^{-1}$ suggested that binding of lipid to protein yielded the hard aggregated yolk, whereas $\mathrm{PbO}_{2}$ at a level of $2 \mathrm{~g} \mathrm{~kg}^{-1}$ treatment rendered the soft yolk containing more free lipids with less association with proteins.

\section{CONCLUSION}

This is the first report on the FTIR study of pidan white and yolk treated with the different cations and found to be different bands which in turn associate with the gelling behavior of the pidan. Interactions with the cations increase the wavenumber and confirms the binding of protein. $\mathrm{PbO}_{2}$ treated pidan white contained higher cross linking of protein than that produced with $\mathrm{ZnCl}_{2}$ treatment at a level of $2 \mathrm{~g} \mathrm{~kg}^{-1}$. Thus cations in the pickling solution affected FTIR characteristics and microstructure of both pidan white and yolk.

\section{ACKNOWLEDGEMENTS}

The authors would like to express their sincere thanks to the Graduate School of Prince of Songkla University for the financial support.

\section{REFERENCES}

Boye, J.I., Ismail,A.A. \& Alli, I. 1996. Effect of physico-chemical factors on the secondary structure of lactoglobulin. Journal of Dairy Research 63: 97-109.

Chang, H.M., Tsai, C.F. \& Li, C.F. 1999. Quantification of racemization of amino acids in alkali-treated duck eggs by micellar capillary electrophoresis. Journal of Agricultural and Food Chemistry 47: 479-484.

Chen, J.W. \& Su, H.P. 2004. A new process for preparing spotsfree pidan. Journal of the Chinese Society of Animal Science 33: 79-88.

Creighton, T.E. 1993. Proteins in solution and in membranes. In: Proteins: Structures and Molecular Properties. 2nd ed., edited by Creighton, T.E. New York: W.H. Freeman \& Co.

Ganasen, P. \& Benjakul, S. 2011a. Effects of green tea and Chinese tea on the composition and physical properties of pidan white. Journal of Food Processing \& Technology 35: 907-916.

Ganasen, P. \& Benjakul, S. 2011b. Physical properties and microstructure of pidan white as affected by different divalent and monovalent cations. Journal of Food Biochemistry 35: 1528-1537.

Ganasen, P. \& Benjakul, S. 2010. Physical properties and microstructure of pidan yolk as affected by different divalent and monovalent cations. LWT - Food Science and Technology 43: 77-85.
Guillen, M.D., Ruiz, A. \& Cabo, N. 2004. Study of oxidative degradation of farmed salmon lipids by means of Fourier transform infrared spectroscopy. Influence of salting. Journal of the Science of Food and Agriculture 84: 1528-1534.

Guillén, M.D. \& Cabo, N. 1997. Infrared spectroscopy in the study of edible oils and fats. Journal of the Science of Food and Agriculture 75: 1-11.

Heertje, I. \& van Kleef, F.S.M. 1986. Observations on the microstructure and rheology of ovalbumin gels. Food Microstructure 5: 91-98.

Kiosseoglou, V. 2003. Egg yolk protein gels and emulsions. Current Opinion in Colloid and Interface Science 8: 356-70.

Mineki, M. \& Kobayashi, M. 1997. Microstructure of yolk from fresh eggs by improved method. Journal of Food Science 62: 757-761.

Nagarajan, M., Benjakul, S., Prodpran, T., Songtipya, P. \& Kishimura, H. 2013. Effects of bleaching on characteristics and gelling property of gelatin from splendid squid (Loligo formosana) skin. Food Hydrocolloids 32: 447-452.

Nagarajan, M., Benjakul, S., Prodpran, T., Songtipya, P. \& Kishimura, H. 2012. Characteristics and functional properties of gelatin from splendid squid (Loligo formosana) skin as affected by extraction temperatures. Food Hydrocolloids 29: 389-397.

Setiowaty, G., Che-Man, Y.B., Jinap, S. \& Moh, M.H. 2000. Quantitative determination of peroxide value in thermally oxidised palm olein by Fourier transform infrared spectroscopy. Phytochemical Analysis 11: 74-78.

Steel, R.G.D. \& Torrie, J.H. 1980. Principle and Procedure of Statistics. 2nd ed. New York: McGraw-Hill.

Van de Voort, F.R., Ismail, A.A., Sedman, J. \& Emo, G. 1994. Monitoring the oxidation of edible oils by transform infrared spectroscopy. Journal of the American Chemical Society 71: 243-253.

Woodward,S.A. \& Cotterill, O.J. 1987. Texture and microstructure of cooked whole egg and heat-formed gels of stirred egg yolk. Journal of Food Science 52: 63-67.

Palanivel Ganesan* \& Badlishah Sham Baharin

Department of Food Technology

Faculty of Food Science and Technology

Universiti Putra Malaysia

43400 Serdang, Selangor

Malaysia

Palanivel Ganesan* \& Soottawat Benjakul

Department of Food Technology, Faculty of Agro-Industry

Prince of Songkla University

Hat Yai, Songkhla, 90112

Thailand

*Corresponding author; email: palanivel@upm.edu.my

Received: 25 September 2013

Accepted: 2 May 2014 